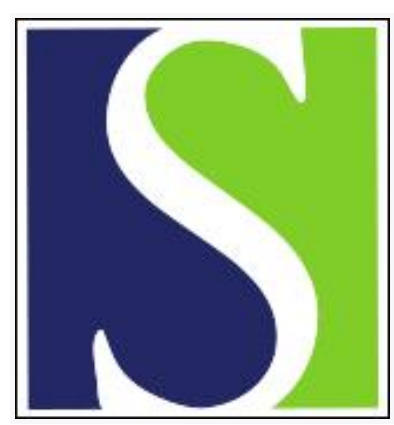

Scand J Work Environ Health 1985;11(5):331-345

https://doi.org/10.5271/sjweh.2215

Issue date: Oct 1985

Mortality among employees of lead battery plants and lead-producing plants, 1947-1980.

by Cooper WC, Wong O, Kheifets L

The following articles refer to this text: 1990;16(2):147-148;

1989;15(4):245-264

This article in PubMed: www.ncbi.nlm.nih.gov/pubmed/4070998

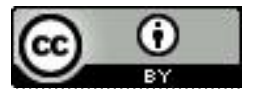




\title{
Mortality among employees of lead battery plants and lead-producing plants, $1947-1980$
}

\author{
by W Clark Cooper MD, ${ }^{1}$ Otto Wong, ScD, ${ }^{2}$ Leeka Kheifets, $\mathrm{MA}^{2}$
}

\begin{abstract}
COOPER WC, WONG O, KHEIFETS L. Mortality among employees of lead battery plants and lead producing plants, 1947 - 1980. Scand J Work Environ Health 11 (1985) 331 - 345. Two cohorts of male lead workers, 4519 battery plant workers and 2300 lead production workers, all of whom had been employed for at least one year during the period 1 January 1946 through 31 December 1970, were observed for mortality during the 34 years from 1 January 1947 through 31 December 1980 . Vital status as of the closing date was determined for $94.7 \%$ of the former group and $91.6 \%$ of the latter. There were 1718 deaths in the first cohort and 621 in the second. Mortality from all causes combined was significantly greater than expected in each cohort, the standardized mortality ratio (SMR) being 107 and 113, respectively. Among the battery plant workers the greater than expected mortality rate resulted in large part from a significant number of excess deaths from malignant neoplasms (SMR 113), other hypertensive disease (mainly renal) (SMR 320), chronic nephritis (SMR 222), and a group of ill-defined conditions (SMR 355). Among the lead production workers the pattern was similar, with a significant number of excess deaths from other hypertensive disease (SMR 475), hypertensive heart disease (SMR 203), chronic nephritis (SMR 265), and ill-defined conditions (SMR 214). There was also a significant excess of deaths from external causes (SMR 143). The SMR for total malignancies was 113, but this value was not significantly elevated at the $5 \%$ level. In neither cohort were deaths from cerebrovascular disease in significant excess, the SMR being 93 and 132, respectively. A proportionate mortality analysis showed that the excess deaths from cerebrovascular disease and from hypertensive heart disease among smelter workers were in part due to the high proportion of nonwhites in the smelter populations. The stomach, liver, and lungs were the sites responsible for most excess cancer deaths in both cohorts, but the elevated SMR values were statistically significant only for gastric and lung cancers in battery plant workers. There were no excess deaths from malignancies of the kidney, brain, or lymphopoeitic system in either cohort. It is impossible to relate the observed mortality to levels of lead exposure; because of meager quantitative information prior to 1960 . It is known that past exposures had been very high. Ethnicity, diet, alcohol, and cigarette smoking could not be ruled out as possible confounding etiologic factors for the cancer deaths.
\end{abstract}

Key terms: battery plants, chronic renal disease, gastric cancer, lead, lung cancer, smelters.

This report updates a study of mortality among 7032 male lead workers which was completed in 1974 and published in 1975 and $1976(12,13,43)$. The original cohorts consisted of 4680 men who had worked in battery plants and 2352 men employed in lead-producing facilities for at least one year between 1 January 1946 and 31 December 1970. Analyses were made of 1356 deaths in the years 1947 through 1970, 1014 battery plant workers and 342 lead production workers, sometimes referred to as smelter workers.

Many of those in the cohort had begun work before World War I. Urinary and blood lead levels available from 10 plants during the period 1947 through 1972 showed that heavy exposure to lead had been common. Overall mortality was found to be approximately the same as that of the total male population, but there was an excess of deaths from chronic

\footnotetext{
1 Occupational Health Consultant, Lafayette, California, United States.

2 Environmental Health Associates, Inc, Oakland, California, United States.
}

Reprint Requests to: Dr WC Cooper, 3687 Mount Diablo Blvd (Suite 320), Lafayette, CA 94549, USA. renal disease. There was also a moderate but not statistically significant excess of deaths from malignancies in the smelter population [standardized mortality ratio (SMR) 133] and the battery plant workers (SMR 111), attributable to small excesses of gastrointestinal tract cancer and lung cancer. It was impossible to correlate these excesses with level or duration of exposure, and it was not felt that the associations were strong enough to categorize lead as a carcinogen or cocarcinogen.

In $1978(10,11), 591$ additional deaths which occurred in the cohorts during $1971-1975$ were the subject of a second analysis, which did not resolve the uncertainties of the first study. Deaths from all causes combined were more than expected in both groups, the SMR for battery plants being 117 and that for smelteries being 108. Cancer deaths of smelter workers were fewer than expected (SMR 89), while for the battery plant workers the SMR for malignancies was 136, largely explained by a slight excess of cancers of the respiratory system (SMR 128) and an excess for "other and unspecified sites." No excess kidney tumors were found. The excess deaths from renal disease seen in 1947-1970 did not occur in 1971-1975. 
The present report extends observation through 1980 and analyzes mortality for the entire period of 34 years, 1947-1980; 2339 deaths occurred from 1 January 1947 through 31 December 1980 during 150091 person-years of observation. Because of differences in age distribution, geographic location, and exposures, the cohorts from the battery plants and the leadproducing plants have been kept separate in all analyses of data. Since both groups had potential exposure to lead, however, the data have been presented in a manner that will permit comparisons.

Rigorous editing of the data base to ensure strict adherance to the study criteria reduced the total size of the cohort from 7 032, (4 680 battery plant workers and 2352 smelter workers), to 6819 (4 519 battery plant workers and 2300 smelter workers). This process eliminated 35 certified deaths included in earlier analyses, but the distribution of causes was such that results were not appreciably affected.

\section{Methods}

\section{Plants chosen for study}

The selection of the original study population has been summarized in earlier reports $(12,43)$. It was based upon responses to questionnaires outlining the proposed study and sent in 1968 to 101 plants in the United States (US) that were members of the International Lead Zinc Research Organization, Inc, the Lead Industries Association, Inc, or the Battery Council International. Eighty-four indicated willingness to participate. From this number six lead production facilities (one primary smeltery, two secondary smelteries and three recycling plants) and 10 battery plants were chosen. A major determinant in selection was the quality and availability of personnel records.

\section{Collection of information}

Microfilmed personnel records from the selected plants provided information on over 24000 individuals who had worked at some time between 1 January 1946 and 31 December 1970. Female employees were excluded because there were too few in production jobs in the early days for meaningful analysis. After their exclusion and the elimination of men with less than a year's employment, or with missing birth or hire dates, 7032 men were selected for the initial study. This group, without major revision, was the population studied in the $1971-1975$ follow-up.

For the present updated study, the exclusion of individuals not meeting study criteria reduced the total population studied from 4680 to 4519 in the battery plants and from 2352 to 2300 in the smelteries.

No new information was added other than that obtained from the follow-up, ie, vital status or job termination. No attempt was made to modify or update exposure histories or job titles.

\section{Follow-up}

There have been three follow-ups of the study cohorts; those through 1970 and 1975 were described in earlier reports.

The present follow-up, through 31 December 1980 , began with the submission of lists of employees alive or of unknown status as of 1 January 1975 to each of the participating plants to determine whether they (i) were still working; (ii) had terminated employment, with date of termination; (iii) were known to be alive; or (iv) were known to be dead, with date and place if known. After receipt of the foregoing information, the names and social security numbers of those whose vital status was still not known were sent to the Social Security Administration (SSA). SSA reports indicated which men (i) were presumably alive because of continuing payments from an employer or benefits being paid out, (ii) had been reported dead, or (iii) were of unknown vital status.

\section{Determining and coding causes of death}

For all men reported as dead, either by the plant or by the SSA, requests for death certificates were sent to states of residence or states where the deaths occurred.

Causes of death were coded by an experienced nosologist, in conformity with the seventh or 1955 revision of the International Classification of Diseases, Injuries, and Causes of Death (ICD) (50). This procedure involved translation of the categories used in the eighth or 1965 revision (34) into appropriate 1955 categories.

For some of the causes of death that are of special interest in the present study, there were important changes in classifications between the seventh and eighth revisions. One example is in the area of hypertension and renal disease, to be discussed later.

The numbers of deaths for which death certificates were not obtained are indicated in the individual tables. Based on the assumption that the causes of death in these cases had the same distribution as in those that were certified, the cause-specific SMR values or proportionate mortality ratio (PMR) values should be increased proportionately. Adjustments of the SMR values for missing certificates were made in all tables in the first report, but not in later versions.

\section{Estimates of exposure}

There is no way of estimating the actual lead exposure of individual members of the cohorts except for the 2275 men for whom data on urinary lead concentrations were obtained and for the 1860 for whom blood lead concentrations were obtained. Most members of the cohorts had been exposed prior to the initiation of monitoring programs. In the period $1947-1972$, for which monitoring information was available, for 1550 men with 10 or more urinary lead determinations, the mean of the battery plant workers 
was $129.7 \mu \mathrm{g} / \mathrm{l}(6.3 \mu \mathrm{mol} / \mathrm{l})$ and that of the lead production workers was $173.2 \mu \mathrm{g} / 1(8.4 \mu \mathrm{mol} / \mathrm{l})$. In both groups there were many individuals with mean urinary lead levels above $150,200,250$, or even $300 \mu \mathrm{g} / \mathrm{l}$ $(9.7-14.5 \mu \mathrm{mol} / \mathrm{l})$.

The mean blood lead concentration of 1326 battery plant workers with three or more analyses was $62.7 \mu \mathrm{g} /$ $100 \mathrm{~g}(3.0 \mu \mathrm{mol} / \mathrm{l}) ; 1009 \mathrm{had}$ working life means of $40 \mu \mathrm{g} / 100 \mathrm{~g}(1.9 \mu \mathrm{mol} / \mathrm{l})$ or more; $278 \mathrm{had}$ means of $70 \mu \mathrm{g} / 100 \mathrm{~g}(3.4 \mu \mathrm{mol} / \mathrm{l})$ or more; $102 \mathrm{had}$ means of $80 \mu \mathrm{g} / 100 \mathrm{~g}(3.9 \mu \mathrm{mol} / \mathrm{l})$ or more; and $24 \mathrm{had}$ means over $100 \mu \mathrm{g} / 100 \mathrm{~g}(4.8 \mu \mathrm{mol} / \mathrm{l})$. For the lead production workers in four plants, the mean for 537 men was $79.7 \mu \mathrm{g} / 100 \mathrm{~g}(3.9 \mu \mathrm{mol} / \mathrm{l}), 241,89,56$, and 18 being over $40,70,80$, and $100 \mu \mathrm{g} / 100 \mathrm{~g}$, respectively (1.9, $3.4,3.9$ and $4.8 \mu \mathrm{mol} / \mathrm{l})$.

No separate analysis of deaths was made for those with monitoring information, due to the fact that most of the determinations were made after 1960 and did not accurately represent individual earlier exposures. The information served, however, as evidence that much of the population under study had been exposed to lead in amounts far above current standards.

\section{Analysis of data}

Cohort members were considered as under observation for mortality after completion of one year of employment, if hired after 1 January 1946, or on 1 January 1947, if hired on or before 1 January 1946. Those whose vital status was unknown as of the close of the observation period, 31 December 1980, were considered as under observation until the last date they were known to be alive, usually the day of termination of employment. This is a compromise between dropping them from the study entirely, which would underestimate the person-years at risk, or treating them as alive until 31 December 1980, which would overestimate the persori-years at risk. In any event, the numbers involved do not seriously affect the final result.

The SMR values were calculated using the Occupational Cohort Mortality Analysis Program or OCMAP (29). The rates used for comparison were those for US white males from Monson's US seventh and eighth revision death rate files (32), translated to conform to the seventh revision classification. The only death rates available for entry in the OCMAP computer programs are based on mortality in the US as a whole, so it was not possible to develop comparative data based upon the actual geographic distribution of the populations under study.

Deaths attributed to chronic renal disease required special treatment. Rates available in the computerized program were not in sufficient detail to give expected deaths for some causes of interest. They were therefore calculated by hand from tables in reports of US vital statistics for 1952, 1957, 1963, 1967, 1972, and 1977.
Race or ethnic origin is not shown on most personnel records, so it was not possible to calculate SMR values with this information taken into account. Color or race is shown on death certificates, however, and could be considered in the determination of the PMR values and in the review of selected causes of death.

The PMR values were also calculated by use of the OCMAP program. The numbers of deaths due to selected causes were compared with the numbers expected if the distribution of causes had been the same as for US deaths of men the same age and racial distribution (white versus nonwhite) during the same time period.

\section{Tests of statistical significance}

Deviations of the SMR and PMR values from 100 were tested for statistical significance by a method assuming a Poisson distribution $(4,26,27)$. After most of the SMR and PMR values in the tables, the $95 \%$ confidence limits are shown. Confidence levels should be treated with caution when the number of observed deaths was 5 or less, even though the statistical test may indicate significance. A two-tailed test of significance was used.

\section{Results}

\section{Description of the study populations}

There were 4519 battery plant workers and 2300 lead smelter and refinery workers who qualified for the study, a total of 6819 . This is 213 fewer than in the cohorts analyzed in the 1947-1970 study, because of editing of the data base.

The battery plants were located in California, Illinois, Pennsylvania $(\mathrm{N}=3)$, Oregon, Texas $(\mathrm{N}=3)$, and Wisconsin. Pennsylvania-based workers dominated the group, supplying $69.7 \%$ of the total cohort, Texas supplying $9.8 \%$, California $7.5 \%$, Illinois $5.9 \%$, Wisconsin $4.8 \%$, and Oregon $2.3 \%$. The leadproducing plants were located in California $(\mathrm{N}=2)$, Indiana, Montana, Nebraska, and Pennsylvania, Nebraska supplying $35.1 \%$ of the cohort, Indiana $23.2 \%$, Montana $18.9 \%$, Pennsylvania $15.8 \%$, and California $7.0 \%$.

The battery plant workers, on the average, began working in lead industries earlier than did those in the lead-producing plants. Approximately $30 \%$ of the former cohort had been hired before 1940, compared with $12.7 \%$ of the latter; the percentages hired before 1950 were 65 and 41 , respectively.

The battery plant cohort was older, the median year of birth having been in the period 1915-1919, while the median for the lead production workers was in the quinquennium $1920-1924$. About $46 \%$ of the battery plant workers and $30 \%$ of the lead production workers would have been 65 years of age by 1980 . 


\section{Results of the follow-up and death certificate search}

The results of the follow-up are summarized in table 1 , showing that the vital status of $5.3 \%$ of the battery plant cohort and $8.4 \%$ of the lead producing plant cohort was not known as of the close of the observation period. There was a higher proportion of deaths in the former cohort (38\%) than in the latter $(27 \%)$. Death certificates were obtained for $95.2 \%$ of the battery plant deaths and for $93.2 \%$ of the production plant deaths. Of the 1636 certified deaths in battery plants, $6.6 \%$ were of nonwhite workers, com-

Table 1. Results of the follow-up and death certificate search.

\begin{tabular}{|c|c|c|c|c|}
\hline \multirow{2}{*}{$\begin{array}{l}\text { Alive } 31 \text { December } \\
1980\end{array}$} & \multicolumn{2}{|c|}{$\begin{array}{l}\text { Battery } \\
\text { plants }\end{array}$} & \multicolumn{2}{|c|}{$\begin{array}{l}\text { Lead-producing } \\
\text { plants }\end{array}$} \\
\hline & 2562 & (56.7\%) & 1486 & $(64.6 \%)$ \\
\hline $\begin{array}{l}\text { Dead } 31 \text { December } \\
1980 \\
\text { Certificate } \\
\text { No certificate }\end{array}$ & $\begin{array}{r}1718 \\
1636 \\
82\end{array}$ & $(38.0 \%)$ & $\begin{array}{r}621 \\
579 \\
42\end{array}$ & $(27.0 \%)$ \\
\hline $\begin{array}{l}\text { Unknown } 31 \text { December } \\
1980\end{array}$ & 239 & $(5.3 \%)$ & 193 & $(8.4 \%)$ \\
\hline Total cohort & 4519 & $(100.0 \%)$ & 2300 & $(100.0 \%)$ \\
\hline
\end{tabular}

pared with $25 \%$ of the 579 certified deaths in leadproducing plants.

\section{Standardized mortality ratios for the battery plant workers}

The observed and expected deaths for the cohort of 4519 battery plant workers during $1947-1980$ are shown in table 2 . There was a statistically significant excess of total deaths, the SMR being 107. There was also a significant excess of deaths due to malignant neoplasms, 344 observed with 303.4 expected, for an SMR of 113 (119 if corrected for missing certificates). The excess was largely explained by higher than expected deaths for malignancies of the stomach (SMR 168 ) and of the respiratory system (SMR 124). There were no excess deaths from malignancies of the kidney, brain, or lymphopoietic system. Under the category of diseases which includes stroke, ie, vascular lesions of the central nervous system, there was no excess (SMR 93). Deaths from diseases of the circulatory system were the same as for the reference population (SMR 100), the low SMR of 94 for arteriosclerotic heart disease being offset by excess deaths from other causes, including "other hypertensive disease" (ICD 444-447). This group includes hypertension and related renal disease without mention of heart disease.

Table 2. Observed and expected deaths in 1947-1980 among 4519 men employed in lead battery plants for at least one year between 1 January 1946 and 31 December 1970 - Comparison with US white male rates. ${ }^{a}$

\begin{tabular}{|c|c|c|c|c|}
\hline \multirow{2}{*}{ Cause of death ${ }^{b}$} & \multicolumn{2}{|c|}{ Deaths } & \multirow{2}{*}{$\begin{array}{l}\text { Standardized } \\
\text { mortality } \\
\text { ratio }\end{array}$} & \multirow{2}{*}{$\begin{array}{l}95 \% \\
\text { confidence } \\
\text { limits }\end{array}$} \\
\hline & Observed & Expected & & \\
\hline All malignant neoplasms $(140-205)$ & 344 & 303.4 & $113^{*}$ & $102-126$ \\
\hline $\begin{array}{l}\text { Digestive organs and peritoneum (150-159) } \\
\text { Stomach (151) } \\
\text { Large intestine (153) } \\
\text { Liver (155) } \\
\text { Respiratory system (160-164) } \\
\text { Larynx (161) } \\
\text { Bronchus, trachea, lung (162-163) } \\
\text { Kidney (180) } \\
\text { Brain and other central nervous system (193) } \\
\text { Lymphopoietic system (200-205) }\end{array}$ & $\begin{array}{r}112 \\
34 \\
30 \\
12 \\
116 \\
6 \\
109 \\
3 \\
8 \\
27\end{array}$ & $\begin{array}{r}93.7 \\
20.2 \\
28.8 \\
7.0 \\
93.5 \\
4.7 \\
87.8 \\
7.3 \\
7.7 \\
28.4\end{array}$ & $\begin{array}{l}120 \\
168^{\star \star} \\
104 \\
172 \\
124^{\star} \\
128 \\
124^{\star} \\
41 \\
105 \\
95\end{array}$ & $\begin{array}{r}98-144 \\
116-235 \\
71-149 \\
89-300 \\
103-149 \\
47-280 \\
102-150 \\
9-121 \\
45-206 \\
63-139\end{array}$ \\
\hline Vascular lesions, central nervous system $(330-334)$ & 122 & 131.6 & 93 & $77-111$ \\
\hline All diseases, circulatory system $(400-468)$ & 760 & 757.7 & 100 & $93-108$ \\
\hline $\begin{array}{l}\text { Arteriosclerotic heart disease }(420) \\
\text { Hypertensive heart disease }(440-443) \\
\text { Other hypertensive disease }(444-447)\end{array}$ & $\begin{array}{r}563 \\
35 \\
21\end{array}$ & $\begin{array}{r}601.1 \\
27.4 \\
6.6\end{array}$ & $\begin{array}{l}94 \\
128 \\
320^{\star *}\end{array}$ & $\begin{array}{r}86-102 \\
89-178 \\
197-489\end{array}$ \\
\hline Nonmalignant respiratory disease $(470-527)$ & 91 & 92.5 & 98 & $79-121$ \\
\hline Cirrhosis of liver (581) & 43 & 32.9 & 131 & $95-176$ \\
\hline Chronic or unspecified nephritis $(592-594)$ & 20 & 9.0 & $222^{\star \star}$ & $135-343$ \\
\hline Chronic nephritis (592) & 14 & 8.8 & 159 & $87-267$ \\
\hline III-defined conditions $(780-795)$ & 56 & 15.7 & $355^{\star \star}$ & $268-462$ \\
\hline All external causes (800-998) & 95 & 122.0 & $78^{\star}$ & $63-95$ \\
\hline $\begin{array}{l}\text { All accidents }(800-962) \\
\text { Motor vehicle accidents }(810-835) \\
\text { Suicide }(963,970-979)\end{array}$ & $\begin{array}{l}66 \\
28 \\
21\end{array}$ & $\begin{array}{l}84.1 \\
36.9 \\
29.1\end{array}$ & $\begin{array}{l}79^{*} \\
76 \\
72\end{array}$ & $\begin{array}{l}61-100 \\
51-110 \\
45-110\end{array}$ \\
\hline Cause unknown & 82 & - & . & - \\
\hline $\begin{array}{l}\text { All causes }(001-998) \\
\text { All causes with death certificates }\end{array}$ & $\begin{array}{l}1718 \\
1636\end{array}$ & 1611.3 & $107^{\star \star}$ & $102-112$ \\
\hline
\end{tabular}

a Number of workers 4519 , number of person-years 99992 , deaths per 1000 person-years 17.2 , correction factor for missing death certificates $5.0 \%$.

b Number of the International Classification of Diseases (seventh revision) in parentheses.

* Significantly different from 100 at the $5 \%$ level, ie, $p<0.05 ;{ }^{\star}$ at the $1 \%$ level, ie, $p<0.01$. 
The excess in this category ( 21 deaths with $6.6 \mathrm{ex}-$ pected, for a highly significant SMR of 320) was in addition to the increased number of deaths due to "chronic or unspecified nephritis" (ICD 592-594), for which the SMR was 222. Another unusual finding was the large number of deaths attributed to "illdefined and unknown causes," 56 observed with 15.7 expected, for a highly significant SMR of 355 . These deaths will be subjected to more detailed review in a later section.

\section{Standardized mortality ratios for the lead- producing plants}

The mortality for the total cohort of 2300 workers during 1947-1980 is summarized in table 3. Again the SMR for all causes of death combined was significantly elevated, being 113. The SMR for deaths from malignancies was also 113 , but this was not statistically significant at the $95 \%$ level because of smaller numbers. The SMR for digestive tract malignancies was 118, that for the subgroup representing stomach cancers being 146, (9 with 6.2 expected); that for lung cancer was 125. These elevations in site-specific rates were not statistically significant. Again there were no excess kidney, brain, or lymphopoietic cancers.
There was a slight, but statistically insignificant excess of deaths due to vascular lesions of the central nervous system (SMR 132), and a significant deficit of deaths from arteriosclerotic heart disease (SMR 76). There were statistically significant excess deaths from "hypertensive heart disease" and "other hypertensive disease," with SMR values of 203 and 475, respectively. Deaths from chronic or unspecified nephritis were also in excess, the SMR being 265 . It should be pointed out, however, that expected numbers are based on white male death rates, whereas $25 \%$ of the deaths among smelter workers were of nonwhites; for many of these causes, death rates are higher for nonwhites.

As in the battery plants, there was a significant excess in the number of deaths from "ill-defined and unknown causes" (SMR 214) and a significant excess of deaths from external causes (SMR 143). The latter involved total accidents, motor vehicle accidents, other accidents, and suicides.

Of the 26 accidental deaths among smelter workers other than motor vehicle accidents, only six were occupational, the causes being listed as poisoning by exposure to furnace fumes, falling, being struck by descending platform, being crushed by a crane, being caught in machinery, and falling into furnace.

Table 3. Observed and expected deaths in 1947-1980 in a cohort of 2300 workers employed in lead production facilities for at least one year between 1 January 1946 and 31 December 1970 - Comparison with US white male rates. ${ }^{2}$

\begin{tabular}{|c|c|c|c|c|}
\hline \multirow{2}{*}{ Cause of death ${ }^{b}$} & \multicolumn{2}{|c|}{ Deaths } & \multirow{2}{*}{$\begin{array}{l}\text { Standardized } \\
\text { mortality } \\
\text { ratio }\end{array}$} & \multirow{2}{*}{$\begin{array}{l}95 \% \\
\text { confidence } \\
\text { limits }\end{array}$} \\
\hline & Observed & Expected & & \\
\hline All malignant neoplasms $(140-205)$ & 120 & 105.9 & 113 & $94-136$ \\
\hline $\begin{array}{l}\text { Digestive organs and peritoneum (150-159) } \\
\text { Stomach (151) } \\
\text { Large intestine (153) } \\
\text { Liver (155) } \\
\text { Respiratory system (160-164) } \\
\text { Larynx (161) } \\
\text { Bronchus, trachea, lung (162-163) } \\
\text { Kidney (180) } \\
\text { Brain and other central nervous system (193) } \\
\text { Lymphopoietic system (200-205) }\end{array}$ & $\begin{array}{r}36 \\
9 \\
6 \\
4 \\
43 \\
2 \\
41 \\
2 \\
2 \\
3 \\
10\end{array}$ & $\begin{array}{r}30.5 \\
6.2 \\
9.5 \\
2.2 \\
34.9 \\
1.6 \\
32.9 \\
2.7 \\
3.3 \\
10.7\end{array}$ & $\begin{array}{r}118 \\
146 \\
63 \\
184 \\
123 \\
122 \\
125 \\
75 \\
90 \\
94\end{array}$ & $\begin{array}{r}83-164 \\
67-278 \\
23-138 \\
50-471 \\
89-166 \\
15-441 \\
89-169 \\
9-270 \\
19-264 \\
45-172\end{array}$ \\
\hline Vascular lesions, central nervous system $(300-334)$ & 50 & 37.8 & 132 & $98-175$ \\
\hline All diseases, circulatory system $(400-468)$ & 224 & 247.2 & 91 & $79-103$ \\
\hline $\begin{array}{l}\text { Arteriosclerotic heart disease }(420) \\
\text { Hypertensive heart disease }(440-443) \\
\text { Other hypertensive disease }(444-447)\end{array}$ & $\begin{array}{r}152 \\
15 \\
9\end{array}$ & $\begin{array}{r}200.0 \\
7.4 \\
1.9\end{array}$ & $\begin{array}{l}76^{\star \star} \\
203^{\star} \\
475^{\star \star}\end{array}$ & $\begin{array}{r}64-89 \\
113-335 \\
218-902\end{array}$ \\
\hline Nonmalignant respiratory disease $(470-527)$ & 26 & 29.8 & 87 & $57-128$ \\
\hline Cirrhosis of liver (581) & 10 & 14.3 & 70 & $34-129$ \\
\hline Chronic or unspecified nephritis (592-594) & 8 & 3.0 & $265^{*}$ & $114-522$ \\
\hline Chronic nephritis (592) & 5 & 2.9 & 170 & $55-397$ \\
\hline III-defined conditions $(780-795)$ & 13 & 6.1 & $214^{*}$ & $114-366$ \\
\hline All external causes $(800-998)$ & 81 & 56.6 & $143^{* *}$ & $114-178$ \\
\hline $\begin{array}{l}\text { All accidents }(800-962) \\
\text { Motor vehicle accidents }(810-835) \\
\text { Suicide }(963,970-979)\end{array}$ & $\begin{array}{l}48 \\
22 \\
21\end{array}$ & $\begin{array}{l}38.6 \\
18.2 \\
13.2\end{array}$ & $\begin{array}{l}124 \\
121 \\
159\end{array}$ & $\begin{array}{l}92-165 \\
76-184 \\
98-243\end{array}$ \\
\hline Cause unknown & 42 & . & . & . \\
\hline $\begin{array}{l}\text { All causes }(001-998) \\
\text { All causes with death certificates }\end{array}$ & $\begin{array}{l}621 \\
579\end{array}$ & 549.95 & $113^{* *}$ & $104-122$ \\
\hline
\end{tabular}

a Number of workers 2300 , number of person-years 50089 , deaths $/ 1000$ person-years 12.4 , correction factor for missing death certificates $7.25 \%$.

b Number of the International Classification of Diseases (seventh revision) in parentheses.

* Significantly different from 100 at the $5 \%$ level, ie, $p<0.05$; ${ }^{* *}$ at the $1 \%$ level, ie, $p<0.01$. 


\section{Comparison of men hired before 1946 with those hired after}

In table 4 , the mortality of the battery plant workers hired before 1 January 1946 is compared with those hired later. The former subcohort, which represented $57 \%$ of the total battery worker cohort, had $89 \%$ of the deaths, reflecting of course the men's greater age. The mortality pattern is essentially like that of the total cohort, but the higher SMR for cancer of the respiratory tract among those hired after 1946 is of interest. Seventeen of the 21 deaths from other hypertensive disease and all 20 of the deaths from chronic nephritis occurred among men hired before 1946.

Similar comparisons between the subcohort of lead production workers hired before 1946 and that hired afterward are made in table 5. The former group represented only $21 \%$ of the total cohort and had $48 \%$ of the deaths. There were few differences in patterns of mortality in the two subcohorts, except for a significant excess of respiratory tract cancer among those hired before 1946, a significant excess of deaths from external causes (including suicide), and a significant deficit of deaths from cardiovascular disease among those hired after 1946. Deaths from chronic renal disease were more prominent in the pre-1946 subcohort.

\section{Mortality related to cumulative years of employment in battery plants}

In table 6, the observed deaths and SMR values of the battery plant workers are shown for subcohorts with differing cumulative years of employment as of $31 \mathrm{De}-$ cember 1970 , in observation periods beginning 20 years after the date of employment. The most obvious finding was the absence of any positive correlations between longer exposure and elevated SMR values.

\section{Mortality related to cumulative years of employment in lead production facilities}

In table 7 similar information is presented on the observed and expected deaths of lead production workers, again based on cumulative years of employment and observation beginning 20 years after the date of hiring. Again, no pattern was apparent.

Table 4. Observed deaths and standardized mortality ratio (SMR) values, 1947-1980, for 4519 men employed in lead battery plants between 1 January 1946 and 31 December 1970 - Comparison with US white male rates.

\begin{tabular}{|c|c|c|c|c|}
\hline \multirow{3}{*}{ Cause of death ${ }^{a}$} & \multicolumn{4}{|c|}{ Hire date } \\
\hline & \multicolumn{2}{|c|}{ Before 1 January $1946^{b}$} & \multicolumn{2}{|c|}{1 January 1946 or laterc } \\
\hline & Observed & SMR & Observed & SMR \\
\hline All malignant neoplasms $(140-205)$ & 297 & 112 & 47 & 125 \\
\hline Digestive organs and peritoneum $(150-159)$ & 105 & $124^{*}$ & 7 & 76 \\
\hline Stomach (151) & 31 & $167^{\star}$ & 3 & 185 \\
\hline Large intestine (153) & 30 & 116 & - & - \\
\hline Liver (155) & 12 & 187 & - & - \\
\hline Respiratory system (160-164) & 92 & 115 & 24 & $181^{\star *}$ \\
\hline Larynx (161) & 5 & 121 & 1 & 184 \\
\hline Bronchus, trachea, lung (162-163) & 86 & 114 & 23 & $183^{*}$ \\
\hline Kidney $(180)$ & 3 & 48 & - & - \\
\hline Brain and other central nervous system (193) & 5 & 85 & 3 & 173 \\
\hline Lymphopoietic system (200-205) & 23 & 97 & 4 & 87 \\
\hline Vascular lesions, central nervous system $(330-334)$ & 117 & 95 & 5 & 58 \\
\hline All diseases, circulatory system $(400-468)$ & 702 & 103 & 58 & $77^{* *}$ \\
\hline Arteriosclerotic heart disease $(420)$ & 522 & 97 & 41 & $65^{* *}$ \\
\hline Hypertensive heart disease $(440-443)$ & 33 & 124 & 2 & 160 \\
\hline Other hypertensive disease $(444-447)$ & 17 & $278^{*}$ & 4 & 908 \\
\hline Nonmalignant respiratory disease $(470-527)$ & 84 & 100 & 7 & 81 \\
\hline Cirrhosis of liver (581) & 35 & 138 & 8 & 106 \\
\hline Chronic or unspecified nephritis $(592-594)$ & 20 & $251^{\star *}$ & - & - \\
\hline Chronic nephritis (592) & 14 & 181 & - & - \\
\hline III-defined conditions $(780-795)$ & 51 & $394^{\star \star}$ & 5 & 177 \\
\hline All external causes $(800-998)$ & 65 & $77^{\star}$ & 30 & 79 \\
\hline All accidents $(800-962)$ & 49 & 83 & 17 & 67 \\
\hline Motor vehicle accidents $(810-835)$ & 22 & 93 & 6 & $46^{\star}$ \\
\hline Suicide $(963,970-979)$ & 14 & 68 & 7 & 83 \\
\hline Cause unknown & 71 & . & 11 & . \\
\hline All causes $(001-998)$ & 1534 & $109^{*}$ & 184 & 93 \\
\hline All causes with death certificates & 1463 & . & 173 & . \\
\hline
\end{tabular}

a Number of the International Classification of Diseases (seventh revision) in parentheses.

b Number of workers 2571 , number of person-years 64019 , deaths $/ 1000$ person-years 23.96 , correction factor for missing death certificates $4.85 \%$

c Number of workers 1948 , number of person-years 35 974, deaths/1 000 person-years 5.11 , correction factor for missing death certificates $6.4 \%$

* Significantly different from 100 at the $95 \%$ the level, ie, $p<0.05 ;{ }^{*}$ at the $99 \%$ level, ie, $p<0.01$. 


\section{Proportionate mortality of the battery}

\section{plant workers}

In table 8 the numbers of observed deaths for various causes is compared with the numbers expected if the distribution of causes were the same as those observed for US white male deaths and nonwhite male deaths during the period $1947-1980$. In the battery plants, $6.6 \%$ of the deaths were of nonwhite workers, compared with 10.5 to $14 \%$ of the entire US during the same time period.

The PMR values were consistent with the SMR values in the same population. There were significant excess deaths from gastric cancer (PMR 154), "other hypertensive disease" (PMR 241), "chronic or unspecified nephritis (PMR 206), and "ill-defined conditions" (PMR 291), and significant deficits in deaths from vascular lesions of the central nervous system (PMR 82), arteriosclerotic heart disease (PMR 88), and external causes (PMR 82).

\section{Proportionate mortality among lead production workers}

In table 9, the PMR values are shown for deaths of lead production workers. There was a much larger proportion of nonwhite workers in this cohort than in the battery plants, $25 \%$ of the deaths having been of nonwhite workers. In this analysis, which takes race into account, there were still significant excess deaths (PMR 388) from "other hypertensive disease," but those from hypertensive heart disease (PMR $=128)$, stomach cancer (PMR 119), and chronic or unspecified nephritis (PMR 186) dropped below the level of $95 \%$ significance. The excess of deaths from external causes (PMR 124) was marginally significant.

\section{Cancer of the gastrointestinal tract}

The elevated SMR values for gastrointestinal tract cancer were largely attributable to cancer of the stomach,

Table 5. Observed deaths and standardized mortality ratio (SMR) values, 1947-1980, for 2300 men employed in lead production facilities for at least one year between 1 January 1946 and 31 December 1970 - Comparison with US white male rates.

\begin{tabular}{|c|c|c|c|c|}
\hline \multirow{3}{*}{ Cause of deatha } & \multicolumn{4}{|c|}{ Hire date } \\
\hline & \multicolumn{2}{|c|}{ Before 1 January $1946^{b}$} & \multicolumn{2}{|c|}{1 January 1946 of later ${ }^{\circ}$} \\
\hline & Observed & SMR & Observed & SMR \\
\hline All malignant neoplasms (140-205) & $58^{-}$ & 119 & 62 & 108 \\
\hline $\begin{array}{l}\text { Digestive organs and peritoneum }(150-159) \\
\text { Stomach (151) } \\
\text { Large intestine (153) } \\
\text { Liver (155) } \\
\text { Respiratory system }(160-164) \\
\text { Larynx (161) } \\
\text { Bronchus, trachea, lung }(162-163) \\
\text { Kidney (180) } \\
\text { Brain and other central nervous system (193) }\end{array}$ & $\begin{array}{r}18 \\
5 \\
4 \\
2 \\
22 \\
\frac{2}{22} \\
2 \\
2\end{array}$ & $\begin{array}{r}116 \\
145 \\
85 \\
168 \\
150 \\
160^{\star} \\
174 \\
183\end{array}$ & $\begin{array}{r}18 \\
4 \\
2 \\
2 \\
21 \\
2 \\
19 \\
-1\end{array}$ & $\begin{array}{r}120 \\
148 \\
42 \\
204 \\
104 \\
229 \\
95 \\
- \\
45\end{array}$ \\
\hline Lymphopoietic system (200-205) & 4 & 93 & 6 & 95 \\
\hline Vascular lesions, central nervous system $(330-334)$ & 29 & 130 & 21 & 136 \\
\hline All diseases, circulatory system $(400-468)$ & 127 & 101 & 97 & $80^{\star}$ \\
\hline $\begin{array}{l}\text { Arteriosclerotic heart disease }(420) \\
\text { Hypertensive heart disease }(440-443) \\
\text { Other hypertensive disease }(444-447)\end{array}$ & $\begin{array}{r}82 \\
11 \\
7\end{array}$ & $\begin{array}{l}83 \\
222^{\star} \\
619^{\star \star}\end{array}$ & $\begin{array}{r}70 \\
4 \\
2\end{array}$ & $\begin{array}{l}69^{* *} \\
166 \\
263\end{array}$ \\
\hline Nonmalignant respiratory disease $(470-527)$ & 15 & 98 & 11 & 76 \\
\hline Cirrhosis of liver (581) & 2 & 43 & 8 & 83 \\
\hline Chronic or unspecified nephritis (592-594) & 6 & $407^{* *}$ & 2 & 130 \\
\hline Chronic nephritis (592) & 3 & 210 & 2 & 132 \\
\hline III-defined conditions (780-795) & 5 & 213 & 8 & 215 \\
\hline All external causes $(800-998)$ & 18 & 118 & 63 & $153^{\star *}$ \\
\hline $\begin{array}{l}\text { All accidents }(800-962) \\
\text { Motor vehicle accidents }(810-835) \\
\text { Suicide }(963,970-979)\end{array}$ & $\begin{array}{r}12 \\
2 \\
4\end{array}$ & $\begin{array}{r}112 \\
47 \\
105\end{array}$ & $\begin{array}{l}36 \\
20 \\
17\end{array}$ & $\begin{array}{l}129 \\
144 \\
181^{\star}\end{array}$ \\
\hline Cause unknown & 14 & . & 28 & . \\
\hline $\begin{array}{l}\text { All causes }(001-998) \\
\text { All causes with death certificates }\end{array}$ & $\begin{array}{l}298 \\
284\end{array}$ & $\begin{array}{l}115^{*} \\
\cdot\end{array}$ & $\begin{array}{l}323 \\
195\end{array}$ & $\begin{array}{c}111 \\
.\end{array}$ \\
\hline
\end{tabular}

a Number of the International Classification of Diseases (seventh revision) in parentheses.

b Number of workers 485, number of person-years 11507 , deaths/1000 person-years 25.9 , correction factor for missing death certificates $4.9 \%$.

c Number of workers 1815 , number of person-years 38482 , deaths 11000 person-years 8.4 , correction factor for missing death certificates $14.4 \%$.

* Significantly different from 100 at the $95 \%$ the level, ie, $p<0.05 ;{ }^{* *}$ at the $99 \%$ level, ie, $p<0.01$. 
although there were less striking excesses for cancer of the large intestine and liver.

Because there are geographic and ethnic factors associated with gastric cancer, the birthplaces of those who died of this cause were recorded from the death certificates. In the battery plants, 13 of 34 deaths were of foreign-born workers (Ireland 6, Scotland 2, Italy 5 ). Among the lead production workers, six of nine were foreign-born (Italy 1, Spain 1, Russia 2, Norway 1, Yugoslavia 1).

Of the 34 battery plant deaths, 31 were in Pennsylvania and three were in Texas. Four $(11.8 \%)$ were of black workers. Of the nine stomach cancer deaths of lead production workers, there were two in Nebraska, two in Montana, three in Indiana, and one each in California and Pennsylvania. Only one was of a black worker.

\section{Chronic renal disease}

In the initial mortality analysis reported in 1975, there were significant excesses of deaths attributed to chronic renal disease, whether classified as "other hypertensive disease" (ICD 444-447 in the seventh revision) or as "chronic or unspecified nephritis" (ICD $592-$ 594). In the eighth revision of the ICD, "other hypertensive disease," which had included hypertensive renal disease without mention of heart disease, became a subcategory of hypertensive disease (ICD 400-404), which was dominated by hypertensive heart disease (ICD 403). Since available computer programs did not contain breakdowns of individual causes in sufficient detail to permit all of the analyses needed, expected deaths were calculated by hand. Irrespective of classifications, US death rates for these causes have been declining in recent years. In addition there are different rates for white and nonwhite populations.

Of the 21 deaths in the battery plants coded under the classification other hypertensive disease (ICD 444-447), 12 were due to hypertension with arteriolar nephrosclerosis (ICD 446), with three each coded as essential benign hypertension (ICD 444), essential malignant hypertension (ICD 445), and other hypertensive disease without mention of the heart (ICD 447). In the production plants, six were coded 446 , and three were coded 445 . Of the deaths due to chronic and unspecified nephritis, 14 of the 20 in the battery plants

Table 6. Observed deaths and standardized mortality ratio (SMR) values, 1947-1980, for 4519 men employed in battery plants for at least one year between 1 January 1946 and 31 December 1970, with various periods of cumulative exposure, during observation periods beginning 20 years after hire - Comparison with US white male rates.

\begin{tabular}{|c|c|c|c|c|c|c|}
\hline \multirow{3}{*}{ Cause of deatha } & \multicolumn{6}{|c|}{ Cumulative years of employment } \\
\hline & \multicolumn{2}{|c|}{$1-9^{b}$} & \multicolumn{2}{|c|}{$10-19^{c}$} & \multicolumn{2}{|c|}{$\geq 20^{d}$} \\
\hline & Observed & SMR & Observed & SMR & Observed & SMR \\
\hline All malignant neoplasms $(140-205)$ & 52 & $151^{\star \star}$ & 52 & 130 & 190 & 104 \\
\hline $\begin{array}{l}\text { Digestive organs and peritoneum (150-159) } \\
\text { Stomach (151) } \\
\text { Large intestine (153) } \\
\text { Liver (155) } \\
\text { Respiratory system (160-164) } \\
\text { Larynx (161) } \\
\text { Bronchus, trachea, lung (162-163) } \\
\text { Kidney (180) } \\
\text { Brain and other central nervous system (193) }\end{array}$ & $\begin{array}{r}13 \\
4 \\
2 \\
2 \\
21 \\
1 \\
20 \\
1 \\
1\end{array}$ & $\begin{array}{l}142 \\
255 \\
66 \\
357 \\
166^{\star} \\
185 \\
167^{\star} \\
112 \\
101\end{array}$ & $\begin{array}{r}14 \\
3 \\
6 \\
- \\
21 \\
\frac{21}{1} \\
-1\end{array}$ & $\begin{array}{r}126 \\
153 \\
163 \\
- \\
147 \\
\frac{156}{101} \\
-\end{array}$ & $\begin{array}{r}70 \\
19 \\
22 \\
9 \\
58 \\
4 \\
53 \\
1 \\
5\end{array}$ & $\begin{array}{r}117 \\
142 \\
120 \\
197 \\
108 \\
141 \\
105 \\
24 \\
145\end{array}$ \\
\hline Lymphopoietic system (200-205) & 3 & 165 & 5 & 141 & 12 & 77 \\
\hline Vascular lesions, central nervous system $(330-334)$ & 9 & 82 & 14 & 100 & 85 & 89 \\
\hline All diseases, circulatory system $(400-468)$ & 61 & 80 & 99 & 109 & 509 & 105 \\
\hline $\begin{array}{l}\text { Arteriosclerotic heart disease }(420) \\
\text { Hypertensive heart disease }(440-443) \\
\text { Other hypertensive disease }(444-447)\end{array}$ & $\begin{array}{r}40 \\
4 \\
6\end{array}$ & $\begin{array}{l}62^{\star \star} \\
\cdots \\
\cdots\end{array}$ & $\begin{array}{r}84 \\
4 \\
3\end{array}$ & $\begin{array}{r}111 \\
\cdots \\
\cdots\end{array}$ & $\begin{array}{r}377 \\
15 \\
10\end{array}$ & $\begin{array}{l}99 \\
\cdots \\
\cdots\end{array}$ \\
\hline Nonmalignant respiratory disease $(470-527)$ & 14 & 143 & 14 & 116 & 59 & 98 \\
\hline Cirrhosis of liver (581) & 4 & 84 & 8 & 177 & 21 & 139 \\
\hline Chronic or unspecified nephritis $(592-594)$ & 2 & . & 1 & . & 14 & . \\
\hline Chronic nephritis (592) & 2 & 370 & 1 & 152 & 10 & 195 \\
\hline Ill-defined conditions $(780-795)$ & 21 & $395^{\star *}$ & 12 & $569^{\star *}$ & 28 & $323^{* *}$ \\
\hline All external causes $(800-998)$ & 40 & 74 & 4 & $37^{\star}$ & 47 & 101 \\
\hline $\begin{array}{l}\text { All accidents }(800-962) \\
\text { Motor vehicle accidents }(810-835) \\
\text { Suicide }(963,970-979)\end{array}$ & $\begin{array}{r}24 \\
9 \\
9\end{array}$ & $\begin{array}{l}65^{\star} \\
50^{\star} \\
75\end{array}$ & $\begin{array}{l}3 \\
1 \\
1\end{array}$ & $\begin{array}{l}42^{\star} \\
36 \\
35\end{array}$ & $\begin{array}{r}37 \\
17 \\
9\end{array}$ & $\begin{array}{r}114 \\
137 \\
77\end{array}$ \\
\hline Cause unknown & 13 & - & 9 & - & 50 & . \\
\hline $\begin{array}{l}\text { All causes }(001-998) \\
\text { All causes with death certificates }\end{array}$ & $\begin{array}{l}188 \\
175\end{array}$ & $\begin{array}{c}115^{\star} \\
.\end{array}$ & $\begin{array}{l}225 \\
216\end{array}$ & $119^{\star}$ & $\begin{array}{l}1071 \\
1021\end{array}$ & $109^{\star \star}$ \\
\hline
\end{tabular}

a Number of the International Classification of Diseases (seventh revision) in parentheses.

b Number of person-years 9959 , deaths 11000 person-years 18.9 , correction factor for missing death certificates $7.4 \%$.

c Number of person-years 8578 , deaths/1000 person-years 26.2, correction factor for missing death certificates $4.2 \%$.

d Number of person-years 31245 , deaths $/ 1000$ person-years 34.3 , correction factor for missing death certificates $4.9 \%$.

* Significantly different from 100 at the $95 \%$ level, ie, $p<0.05 ;{ }^{*}$ at the $99 \%$ level, ie, $p<0.01$. 
were coded chronic nephritis (ICD 592), five being nephritis not specified as acute or chronic (ICD 593) and one being other renal sclerosis (ICD 594). In the production plants there were five deaths coded 592 and three coded 593.

Among the battery plant workers, two $(9.5 \%)$ of 21 deaths due to "other hypertensive disease" and two $(10 \%)$ of the 20 deaths due to chronic nephritis were of nonwhites. All but two of the 41 deaths attributed to these two groups of causes were of men hired before 1950 .

In lead production facilities, there was a higher proportion of nonwhite workers, ie, six of nine deaths attributed to other hypertensive disease and three of eight deaths attributed to chronic nephritis were of black employees, Fifteen of the 17 deaths in these two groups of causes among smelter workers were of men hired before 1950 .

\section{Deaths attributed to "ill-defined causes"}

There was a large excess of deaths among the battery plant workers and a smaller but significant excess of deaths among workers in the lead production facili- ties attributed to causes $780-795$ (seventh revision), ie, "senility or ill-defined conditions." When this group was reviewed, it was found that all of the battery plant workers were from Philadelphia and that 46 of the death certificates had been completed by the medical examiner or coroner with the cause given as either "not determined" or "presumably natural disease." In only four of the 56 deaths did the certificate indicate that an autopsy had been performed. Six $(10.7 \%)$ of the 56 deaths were of black workers.

Of the 13 deaths of lead production workers attributed to this group of causes, 11 also represented coroner or medical examiner reports. Five represented deaths in Philadelphia, three in Montana, one each in Indiana, Mississippi, Arkansas, and Pennsylvania (outside Philadelphia). None had had an autopsy. Five $(38.5 \%)$ of the 13 deaths were of nonwhite workers.

\section{Discussion}

\section{Total deaths}

In both cohorts there were more deaths during the $\mathbf{3 4}$ years of observation than expected, compared with US

Table 7. Observed deaths and standardized mortality ratio (SMR) values, 1947-1980, for 2300 men employed in lead-producing plants for at least one year between 1 January 1946 and 31 December 1970 , with various periods of cumulative exposure, during observation periods beginning 20 years after hire - Comparison with US white male rates.

\begin{tabular}{|c|c|c|c|c|c|c|}
\hline \multirow{3}{*}{ Cause of deatha } & \multicolumn{6}{|c|}{ Cumulative years of employment } \\
\hline & \multicolumn{2}{|c|}{$1-9^{b}$} & \multicolumn{2}{|c|}{$10-19 c$} & \multicolumn{2}{|c|}{$\geq 20^{d}$} \\
\hline & Observed & SMR & Observed & SMR & Observed & SMR \\
\hline All malignant neoplasms $(140-205)$ & 25 & 137 & 13 & 124 & 43 & 99 \\
\hline $\begin{array}{l}\text { Digestive organs and peritoneum }(150-159) \\
\text { Stomach (151) } \\
\text { Large intestine (153) } \\
\text { Liver (155) } \\
\text { Respiratory system }(160-164) \\
\quad \text { Larynx (161) } \\
\text { Bronchus, trachea, lung (162-163) } \\
\text { Kidney (180) } \\
\text { Brain and other central nervous system (193) } \\
\text { Lymphopoietic system (200-205) }\end{array}$ & $\begin{array}{r}8 \\
1 \\
2 \\
-8 \\
1 \\
\frac{7}{-} \\
-3\end{array}$ & $\begin{array}{r}171 \\
132 \\
126 \\
-15 \\
115 \\
833 \\
106 \\
- \\
181\end{array}$ & $\begin{array}{r}\frac{1}{-} \\
\frac{-}{5} \\
\frac{5}{2} \\
\frac{2}{1}\end{array}$ & $\begin{array}{c}68 \\
196 \\
- \\
\overline{139} \\
- \\
147 \\
800 \\
\overline{106}\end{array}$ & $\begin{array}{r}13 \\
3 \\
3 \\
2 \\
19 \\
0 \\
19 \\
-1 \\
2\end{array}$ & $\begin{array}{r}98 \\
110 \\
73 \\
208 \\
126 \\
-\overline{143} \\
\overline{105} \\
53\end{array}$ \\
\hline Vascular lesions, central nervous system $(330-334)$ & 6 & 119 & 6 & 133 & 27 & 146 \\
\hline All diseases, circulatory system $(400-468)$ & 33 & 87 & 29 & 115 & 109 & 102 \\
\hline $\begin{array}{l}\text { Arteriosclerotic heart disease }(420) \\
\text { Hypertensive heart disease }(440-443) \\
\text { Other hypertensive disease }(444-447)\end{array}$ & $\begin{array}{r}22 \\
2 \\
2\end{array}$ & $\begin{array}{l}69 \\
\cdots \\
\cdots\end{array}$ & $\begin{array}{r}24 \\
1 \\
-\end{array}$ & $\begin{array}{l}115 \\
\cdots\end{array}$ & $\begin{array}{r}69 \\
10 \\
5\end{array}$ & $\begin{array}{l}80 \\
\cdots \\
\cdots\end{array}$ \\
\hline Nonmalignant respiratory disease $(470-527)$ & 7 & 143 & 1 & 28 & 14 & 104 \\
\hline Cirrhosis of liver (581) & 3 & 112 & - & . & 1 & 24 \\
\hline Chronic or unspecified nephritis $(592-594)$ & - & - & - & $\ldots$ & 6 & . \\
\hline Chronic nephritis (592) & - & - & - & - & 3 & 300 \\
\hline III-defined conditions (780-795) & 4 & $381^{*}$ & 1 & 59 & 5 & 235 \\
\hline All external causes $(800-998)$ & 6 & 95 & 6 & 208 & 12 & 106 \\
\hline $\begin{array}{l}\text { All accidents }(800-998) \\
\text { Motor vehicle accidents }(810-835) \\
\text { Suicide }(963,970-979)\end{array}$ & $\begin{array}{l}3 \\
2 \\
3\end{array}$ & $\begin{array}{r}77 \\
125 \\
179\end{array}$ & $\frac{2}{2}$ & $\frac{105}{274}$ & $\frac{8}{3}$ & $\frac{104}{102}$ \\
\hline Cause unknown & 9 & . & 3 & - & 15 & . \\
\hline $\begin{array}{l}\text { All causes }(001-998) \\
\text { All causes with death certificates }\end{array}$ & $\begin{array}{l}99 \\
90\end{array}$ & 120 & $\begin{array}{l}66 \\
63\end{array}$ & 126 & $\begin{array}{l}250 \\
235\end{array}$ & $114^{*}$ \\
\hline
\end{tabular}

a Number of the International Classification of Diseases (seventh revision) in parentheses.

b Number of person-years 5513 , deaths/1000 person-years 18.0, correction factor for missing death certificates $10 \%$.

c Number of person-years 2266 , deaths $/ 1000$ person-years 29.1 , correction factor for missing death certificates $4.8 \%$.

d Number of person-years 8292 , deaths $/ 1000$ person-years 30.1 , correction factor for missing death certificates $6.4 \%$.

* Significantly different from 100 at the $95 \%$ level, ie, $p<0.05$. 
white males during the same period. The excesses were greater than would be expected from the proportion of nonwhite workers, estimated as $10 \%$ in battery plants and $25 \%$ in smelteties. Age-adjusted death rates for US nonwhite males during this period were about $25 \%$ greater than those for white males. This difference clearly could not explain the $7 \%$ excess among the battery workers and the $13 \%$ excess among the lead production workers, although it possibly contributed to the latter.

It should be questioned whether it is appropriate to regard the overall excess deaths as only $7 \%$ and $13 \%$ above expected, in view of the fact that most studies of occupational cohorts show SMR values for total deaths well below 100 . Values of $80-85$ are common. This so-called "healthy worker effect," becomes less apparent however as a cohort grows older and the proportion of active workers decreases (48). Occupational cohorts approach the national average as the good health that led to employment and continued work becomes more remote in their life histories. In the present study the trend was demonstrable in analyses not included in the tables. There was a significantly low SMR of 65 during the first 10 years of observation of the battery worker cohort, which rose to 94 in the 10- to 19 -year period, to 110 in the 20 - to 29 -year period, and to 112 in observation periods 30 or more years after hiring.

Nevertheless, without trying to make any quantitative allowance for a "healthy worker effect" in view of many uncertainties (30), one must still regard the overall mortality experience of the lead workers as unfavorable. The elevated SMR values of our cohorts were higher than the SMR of $98.6(754 / 764.7)$ reported by Malcolm \& Barnett (25) for 1898 pensioners from a lead acid battery plant in the United Kingdom. Selevan et al (41) recently reported an SMR of 98 for a cohort of 1987 primary lead smelter workers in Idaho, based on 665 deaths. This was a smeltery which was not included in the present study. The overall unfavorable experience in our study resulted from a number of cause-specific excess deaths, most notably those from (i) malignant neoplasms, (ii) chronic renal disease, and (iii) "ill-defined causes." These groups will be discussed in turn.

\section{Malignant neoplasms}

The SMR for malignant neoplasms was 113 for both the battery plant and lead production workers. This rate would have been 119 and 121 , respectively, if ad-

Table 8. Proportionate mortality ratio (PMR) values for 1718 deaths occurring in 1947-1980 among men employed in battery plants for at least one year between 1 January 1946 and 31 December 1970 - Comparison with US white and nonwhite male death rates.

\begin{tabular}{|c|c|c|c|c|}
\hline \multirow{2}{*}{ Cause of deatha } & \multicolumn{2}{|c|}{ Deaths } & \multirow[b]{2}{*}{ PMR } & \multirow{2}{*}{$\begin{array}{l}95 \% \\
\text { confidence } \\
\text { limits }\end{array}$} \\
\hline & Observed & Expected ${ }^{b}$ & & \\
\hline All malignant neoplasms $(140-205)$ & 344 & 324.8 & 106 & $96-116$ \\
\hline $\begin{array}{l}\text { Digestive organs and peritoneum (150-159) } \\
\text { Stomach (151) } \\
\text { Large intestine (153) } \\
\text { Liver (155) } \\
\text { Respiratory system }(160-164) \\
\text { Larynx (161) } \\
\text { Bronchus, trachea, lung }(162-163) \\
\text { Kidney (180) } \\
\text { Brain and other central nervous system (193) } \\
\text { Lymphopoietic system }(200-205)\end{array}$ & $\begin{array}{r}112 \\
34 \\
30 \\
12 \\
116 \\
6 \\
109 \\
3 \\
8 \\
27\end{array}$ & $\begin{array}{r}101.1 \\
22.1 \\
30.5 \\
7.6 \\
99.9 \\
5.0 \\
93.8 \\
7.5 \\
7.3 \\
29.1\end{array}$ & $\begin{array}{r}111 \\
154^{\star} \\
98 \\
158 \\
116 \\
119 \\
116 \\
40 \\
109 \\
93\end{array}$ & $\begin{array}{r}93-133 \\
111-215 \\
69-140 \\
91-277 \\
97-138 \\
54-265 \\
97-139 \\
13-119 \\
55-218 \\
64-135\end{array}$ \\
\hline Vascular lesions, central nervous system $(330-334)$ & 122 & 149.4 & $82^{\star}$ & $69-97$ \\
\hline All diseases, circulatory system (400-468) & 760 & 811.8 & $94^{*}$ & $89-99$ \\
\hline $\begin{array}{l}\text { Arteriosclerotic heart disease }(420) \\
\text { Hypertensive heart disease }(440-443) \\
\text { Other hypertensive disease }(444-447)\end{array}$ & $\begin{array}{r}563 \\
35 \\
21\end{array}$ & $\begin{array}{r}642.2 \\
32.3 \\
8.7\end{array}$ & $\begin{array}{l}88^{\star \star} \\
109^{\star \star} \\
241^{\star \star}\end{array}$ & $\begin{array}{r}82-94 \\
75-151 \\
149-366\end{array}$ \\
\hline Nonmalignant respiratory disease & 91 & 100.6 & 90 & $74-110$ \\
\hline Cirrhosis of liver $(581)$ & 43 & 33.3 & 129 & $96-173$ \\
\hline Chronic or unspecified nephritis $(592-594)$ & 20 & 9.7 & $206^{\star \star}$ & $126-318$ \\
\hline Chronic nephritis (592) & 14 & 9.4 & 148 & $88-249$ \\
\hline Ill-defined conditions (780-795) & 56 & 19.2 & $291 * *$ & $227-373$ \\
\hline All external causes $(800-998)$ & 95 & 115.7 & $82^{\star}$ & $68-97$ \\
\hline $\begin{array}{l}\text { All accidents }(800-962) \\
\text { Motor vehicle accidents }(810-835) \\
\text { Suicide }(963,970-979)\end{array}$ & $\begin{array}{l}66 \\
28 \\
21\end{array}$ & $\begin{array}{l}78.0 \\
32.5 \\
26.4\end{array}$ & $\begin{array}{l}85 \\
86 \\
80\end{array}$ & $\begin{array}{l}67-106 \\
60-123 \\
52-121\end{array}$ \\
\hline Cause unknown & $82^{c}$ & . & . & . \\
\hline All causes $(001-998)$ & 1718 & 1718 & 100 & . \\
\hline
\end{tabular}

a Number of International Classification of Diseases (seventh revision) in parentheses.

b Expected = number of deaths due to each cause or group of causes if the distribution had been the same as for all deaths among US males during the period 1947-1980, adjusted for whether white or nonwhite.

c Correction factor for missing certificates approximately $5 \%$.

* Significantly different from 100 at the $95 \%$ level, ie, $p<0.05$; * at the $99 \%$ level, ie, $p<0.01$. 
justed for missing death certificates. The elevation among the battery plant workers was statistically significant, while that for smelter workers was not.

We are unaware of any published reports showing an overall excess cancer risk for lead workers. Dingwall-Fordyce \& Lane (15), in a study of battery plant employees and pensioners, concluded that there was no evidence that malignant disease was related to lead exposure. This conclusion was largely based on the lack of a positive association with the levels of exposure. When all their groups were combined, there were 76 deaths, with 65.3 expected (SMR 116), but the excess deaths were not in the highest exposure group. Malcolm \& Barnett (25) found 157 deaths due to neoplasms, with 159.46 expected (SMR 98.5), among 1898 battery plant pensioners. McMichael \& Johnson (31), in a study of proportionate mortality for 140 deaths among Australian lead smelter workers who had had lead poisoning, found fewer cancer deaths than among workers who did not have a history of such poisoning. Even after adjustment for the effect of excess deaths from nonmalignant disease, the proportion of cancer deaths was only $70 \%$ of that of the comparison group. Selevan et al (41) found an SMR for cancer of 95 (116 with 122.1 expected) for lead smelter workers in Idaho.
Primary cancer sites were similarly distributed in our two cohorts, the greatest excesses being for cancers of the gastrointestinal tract and the lung. The patterns were similar to those reported in those cohorts for the years 1947-1970 (9), but larger numbers resulted in some of the associations now being statistically significant.

\section{Gastrointestinal cancer}

The SMR for gastrointestinal cancer in the battery workers was 120 , based on 112 deaths with 93.7 expected, a value just below the level of $95 \%$ significance. The excess was largely explained by 34 gastric cancers with 20.2 expected, for a highly significant SMR of $168(\mathrm{p}<0.01)$. There were also 12 deaths from liver cancer with 7 expected, for an SMR of 172 $(p>0.05)$. The elevations were less for the smelter workers, the SMR for gastrointestinal cancer being 118 , based on 36 deaths with 30.4 expected. Again, the primary sites with the highest, although not significantly elevated, SMR values were the stomach [9 deaths with 6.2 expected (SMR 146)] and the liver [4 deaths with 2.2 expected (SMR 184)].

The incidence of gastric cancer varies greatly in different geographic areas, being particularly high in Ja-

Table 9. Proportionate mortality ratio (PMR) values for 621 deaths occurring in 1947-1980 among men employed in lead production plants for at least one year between 1 January 1946 and 31 December 1970 - Comparison with US white and nonwhite male deaths rates.

\begin{tabular}{|c|c|c|c|c|}
\hline \multirow{2}{*}{ Cause of deatha } & \multicolumn{2}{|c|}{ Deaths } & \multirow[b]{2}{*}{ PMR } & \multirow{2}{*}{$\begin{array}{c}95 \% \\
\text { confidence } \\
\text { limits }\end{array}$} \\
\hline & Observed & Expected ${ }^{b}$ & & \\
\hline All malignant neoplasms $(140-205)$ & 120 & 118.0 & 102 & $87-119$ \\
\hline $\begin{array}{l}\text { Digestive organs and peritoneum (150-159) } \\
\text { Stomach (151) } \\
\text { Large intestine (153) } \\
\text { Liver (155) } \\
\text { Respiratory system (160-164) } \\
\quad \text { Larynx (161) } \\
\text { Bronchus, trachea, lung (162-163) } \\
\text { Kidney (180) } \\
\text { Brain and other central nervous system (193) } \\
\text { Lymphopoietic system (200-205) }\end{array}$ & $\begin{array}{r}36 \\
9 \\
6 \\
4 \\
43 \\
2 \\
41 \\
2 \\
3 \\
10\end{array}$ & $\begin{array}{r}34.8 \\
7.6 \\
9.9 \\
2.6 \\
38.7 \\
1.9 \\
36.4 \\
2.7 \\
3.1 \\
10.9\end{array}$ & $\begin{array}{r}103 \\
119 \\
61 \\
155 \\
111 \\
106 \\
113 \\
74 \\
97 \\
92\end{array}$ & $\begin{array}{l}75-142 \\
62-228 \\
28-133 \\
59-409 \\
83-148 \\
27-421 \\
84-151 \\
19-294 \\
32-301 \\
50-169\end{array}$ \\
\hline Vascular lesions, central nervous system $(330-334)$ & 50 & 48.1 & 104 & $80-135$ \\
\hline All diseases, circulatory system $(400-468)$ & 224 & 266.6 & $84^{* *}$ & $76-93$ \\
\hline $\begin{array}{l}\text { Arteriosclerotic heart disease }(420) \\
\text { Hypertensive heart disease }(440-443) \\
\text { Other hypertensive disease }(444-447)\end{array}$ & $\begin{array}{r}152 \\
15 \\
9\end{array}$ & $\begin{array}{r}208.2 \\
11.7 \\
2.3\end{array}$ & $\begin{array}{r}73^{* *} \\
128^{* *} \\
388^{* *}\end{array}$ & $\begin{array}{r}64-83 \\
71-211 \\
178-736\end{array}$ \\
\hline Nonmalignant respiratory disease $(470-527)$ & 26 & 34.1 & 76 & $53-111$ \\
\hline Girrhosis of liver (581) & 10 & 15.9 & 63 & $35-115$ \\
\hline Chronic or unspecified nephritis (592-594) & 8 & 4.3 & 186 & $80-366$ \\
\hline Chronic nephritis (592) & 5 & 4.2 & 120 & $50-286$ \\
\hline III-defined conditions $(780-795)$ & 13 & 10.2 & 128 & $75-219$ \\
\hline All external causes $(800-998)$ & 81 & 65.4 & $124^{*}$ & $103-149$ \\
\hline $\begin{array}{l}\text { All accidents }(800-962) \\
\text { Motor vehicle accidents }(810-835) \\
\text { Suicide }(963,970-979)\end{array}$ & $\begin{array}{l}48 \\
22 \\
21\end{array}$ & $\begin{array}{l}42.1 \\
19.2 \\
11.6\end{array}$ & $\begin{array}{l}114 \\
115 \\
181^{* *}\end{array}$ & $\begin{array}{r}88-148 \\
78-170 \\
120-273\end{array}$ \\
\hline Cause unknown & $42^{c}$ & . & . & . \\
\hline All causes $(001-998)$ & 621 & 621.0 & 100 & . \\
\hline
\end{tabular}

a Number of International Classification of Diseases (seventh revision) in parentheses.

b Expected = number of deaths due to each cause or group of causes if the distribution had been the same as for all deaths among US males during the period 1947-1980, adjusted for whether white or nonwhite.

c Correction factor for missing certificates approximately $7.25 \%$.

* Significantly different from 100 at the $95 \%$ level, ie, $p<0.05 ;{ }^{* *}$ at the $99 \%$ level, ie, $p<0.01$. 
pan, Costa Rica, Chile, Hungary, and Poland (1). That this is due to diet or factors other than ethnicity is suggested by the frequent tendency of emigrants' descendents to develop rates corresponding to those of their new homes. In the battery plants, 13 of 34 deaths were of foreign-born workers, predominantly from Ireland and Italy. Among the smelter workers, six of nine were foreign-born workers, ie, from Italy, Spain, Russia, Norway, and Yugoslavia. Although these are not countries in the extremely high risk category, all have age-adjusted gastric cancer deaths higher than that of the US. For example, gastric cancer deaths per 100000 in $1978-1979$ were Ireland 21.4 , Italy 31.3 , Norway 21.2, Spain 28.7 in comparison with 8.6 for the US in the same period. The US rate was 20.2 in 1950-1959 and 13.0 in $1960-1969$.

Twenty-nine or $85 \%$ of the 34 gastric cancer deaths among the battery plant workers were of men living in Pennsylvania, which supplied approximately $67 \%$ of the battery worker population, but $89.9 \%$ of the deaths. Gastric cancer rates in Pennsylvania are somewhat higher than in the US as a whole, and those in Philadelphia, where the largest battery plant was located, are even higher (39). For white males, ageadjusted gastric cancer death in the US in the periods $1950-1959,1960-1969$, and $1970-1979$ were 20.2, 13.0 , and 9.0 per 100000 , respectively. Corresponding figures for Pennsylvania were 22.7, 14.1, and 9.7, and for Philadelphia 25.4, 16.6, and 11.6 per 100000 . The Pennsylvania rates have averaged from 8 to $12 \%$ higher than the US rates. Philadelphia rates have averaged between 26 and $29 \%$ higher than US rates during the past 30 years. This occurrence could explain part but not all of the excess deaths in the battery plants. A special analysis of Pennsylvania battery plant mortality done by Tabershaw/Cooper Associates in 1975 using Pennsylvania death rates showed no effect on most of the SMR values, but it did change the SMR for stomach cancers $(1947-1970)$ from 125 to 109 , a $12.8 \%$ reduction. In the absence of knowledge of the proportion of foreign-born and first generation workers in the study cohorts, the actual contribution of such factors cannot be ascertained. The fact that nearly all $(97 \%)$ of the gastric cancer deaths of the battery plant workers occurred of men who began employment in the 1940s or earlier is compatible either with foreign-born or first generation status or with heavy lead exposures during the early days.

There are no published reports which definitely associate lead with gastric cancer. Malcolm \& Barnett (25) reported 21 such deaths with 12.56 expected $(p=0.009)$, based on proportionate mortality of a subgroup of deaths that occurred during employment in high lead exposure areas of a lead battery plant, but this excess was largely confined to the years 1963 1969. There was no such excess found in the SMR for this cause among pensioners in the same plant. Selevan et al (41) reported an SMR of 77 for gastrointes- tinal tract tumors; they did not single out gastric cancer for analysis.

Further study of a possible association between lead and gastric cancer seems desirable. If in fact such an association is confirmed, a plausible hypothesis would be that high local concentrations of ingested lead have a cocarcinogenic effect in those whose dietary or alcoholic intake patterns put them at unusual risk. Lead may interfere with a dietary anticarcinogen (2) or some other protective mechanism (18) and thus may enhance the effect of a primary carcinogen. Speculation on such a mechanism is probably not warranted unless case-(control) referent or other studies strengthen the evidence for an association with lead.

\section{Cancer of the respiratory tract}

It is impossible to draw firm conclusions about lead exposure and the moderate elevations of SMR values for cancer of the respiratory tract (SMR 124 and 123). These were nearly all cancers of the lung (SMR of 124 and 125). These elevations fall within a range that could be explained by a slightly heavier-than-average smoking pattern, common among blue-collar workers $(3,42)$. In the absence of specific evidence, however, they cannot be definitely attributed to smoking. The experimental studies of Kobayashi \& Okamoto (18) previously referred to are relevant in this context. Their work suggested that lead oxide, given concurrently with benzo(a)pyrene by intratracheal injection, had a cocarcinogenic effect in the production of bronchoalveolar neoplastic changes in hamsters. If such were the mechanism of action, it might be an effect which occurred only when lead concentrations exceeded a threshold. This possibility is supported by the observations of Gularek (17), who found that low concentrations of lead had a stimulating effect on immune mechanisms which inhibited tumor cells in vitro, and the work of Wille (49), who reported that ingested lead reduced the number of pulmonary metastases following the intravenous injection of tumor cells into mice.

\section{Cancer of the central nervous system}

There were no excess cancers of the central nervous system. Oyasu et al (36) reported an $8.6 \%$ incidence of gliomas in rats fed diets containing $1 \%$ lead subacetate, compared with $0.3 \%$ among the controls, but such tumors have not been described in other studies in lower animals. A single case of a cerebral tumor in a lead worker was reported by Portal in 1961 (37) to illustrate the problem of differentiating intracranial tumor and lead encephalopathy; there was no suggestion that there was an etiologic relationship.

\section{Renal cancer}

The absence of excess deaths from cancer of the kidney, in spite of a high incidence of nonmalignant renal 
disease, was an interesting finding. Such tumors have been produced in experimental animals by near-lethal doses of lead $(6,7,8,28,40,44,45,46,51,52,53)$. There are reports $(5,22)$ describing single cases of renal cancer in long-term smelter workers. Selevan et al (41) found six renal cancer deaths where 2.94 were expected in a cohort of 1987 male smelter workers in Idaho. In the departments with particularly high lead exposures and relatively low exposures to other materials, the SMR was 301. Since the association was below the level of statistical significance at the $95 \%$ level and was not corroborated by other epidemiologic studies, the authors concluded that the finding had to be interpreted with caution.

\section{Vascular lesions of the central nervous system}

The relatively low incidence of deaths from vascular lesions of the central nervous system contrasts with excess deaths from several other causes commonly associated with hypertension. The rubrics $330-334$ in the seventh revision of the ICD (which correspond in general with rubrics $430-438$ in the eighth revision) include subarachnoid hemorrhage (ICD 330), cerebral hemorrhage (ICD 331), cerebral embolism and thrombosis (ICD 332), spasm of cerebral arteries (ICD 333), and ill-defined vascular lesions of the central nervous system (ICD 334). Effects of trauma are excluded. The distribution of the foregoing causes in the two cohorts was as follows: battery plants, ICD $330=7$; ICD $331=49 ;$ ICD $332=33$; ICD $333=0$; and ICD $334=33$, for a total of 122 ; lead production plants: ICD $330=2$; ICD $331=29$; ICD $332=16$; ICD $333=0$; and $\operatorname{ICD} 334=3$, for a total of 50 . Thus, $45 \%$ of the 172 cerebraovascular disease deaths in the two cohorts were due to cerebral hemorrhage, $28 \%$ to cerebral embolism or thrombosis, and $21 \%$ to illdefined lesions. Only $5 \%$ were due to subarachnoid hemorrhage.

Deaths from this group of causes have been previously reported among lead workers. For example, Dingwall-Fordyce \& Lane (15), in 1963, found that cerebral hemorrhage, cerebral thrombosis, and cerebral arteriosclerosis were the main causes of excess deaths among battery plant pensioners who had had extremely high lead exposures. In their most highly exposed group, there were 24 such deaths with 9.3 expected. Malcolm \& Barnett (25), in a recently updated followup of the same population, found that there were 43 deaths with 33.69 expected in the high exposure subcohort, a significant excess. If one combines all of their groups, 103 deaths from this group of causes were reported with 96.07 expected, for a nonsignificant SMR of 107. This calculation suggests that if a heavilyexposed group could have been defined in our study, the results might have duplicated those from the United Kingdom. Selevan et al (41) reported an SMR for cerebrovascular disease of only 84 for smelter workers, but, when those with 20 or more years of exposure were studied, the SMR was 146 , based on 21 deaths. In our study, lead production workers with 20 or more years of employment also had an SMR of 146 for cerebrovascular disease, based on 27 deaths, whereas a corresponding group of battery plant workers had an SMR of 89 , based on 85 deaths. In our opinion, based on the proportionate mortality analysis, much of the excess among smelter workers was attributable to the high proportion of nonwhite workers.

The possibility, to be discussed later, must be considered that failures of diagnosis might have assigned sudden deaths due to cerebrovascular accidents to the category of ill-defined causes.

\section{Chronic renal disease}

Deaths classified as "other hypertensive disease" were predominantly kidney disease. They, combined with deaths attributed to chronic or unspecified nephritis, accounted for 41 deaths with 15.6 expected among the battery plant workers and 17 deaths with 4.9 expected among the lead production workers. Most of the excess deaths occurred before 1970 and among men who began work before 1946 .

An association between heavy exposure to lead and renal disease is supported by many studies in lower animal species (16). Renal effects in man have been described in clinical reports $(21,24,35)$, by studies of renal function $(14,23,33,38,47)$, and by epidemiologic studies. For example, Lane $(19,20)$ reported nine deaths from chronic azotemic nephritis in a group of about 150 battery plant workers who had spent over 20 years in areas where airborne lead concentrations had often exceeded $500 \mu \mathrm{g} / \mathrm{m}^{3}$. Malcolm \& Barnett (25) reported a small excess of deaths from nephritis and nephrosis among heavily-exposed battery plant pensioners. McMichael \& Johnson (31) reported extremely high standardized PMR values for chronic nephritis in the years 1930-1949 among Australian lead smelter workers. These rates declined by the period 1950-1964, and by 1965-1977 they were about the same as those of other workers. Selevan et al (41) reported nine deaths from chronic nephritis and other renal scleroses (ICD categories 591-594 in the eighth revision) with 4.69 expected (SMR 192) among lead smelter workers employed between 1940 and 1965 .

Because, as Lane (19) pointed out, animals exposed to lead have shown both tubular and vascular changes in the kidneys, it is of interest that in our study there were excess deaths in both the chronic nephritis and the renal vascular disease categories.

\section{Ill-defined causes}

The large number of deaths attributed to ill-defined or undetermined causes, while an unusual finding in an occupational epidemiologic study, cannot be specifically related to lead. One can speculate as to why so many deaths were the subject of investigation by 
a medical examiner or coroner. This is usually done when there has been a sudden and unexpected death in the absence of known illness and active medical attention, the principal objective being to rule out foul play. In many cases there is no attempt to make a definitive diagnosis. Although it is possible that some of these cases represented undiagnosed cerebrovascular accidents, there is no objective basis for such a conclusion.

\section{Relation to levels of exposure}

A major shortcoming of this epidemiologic study is the lack of quantitative information on the actual exposures of the populations at risk. There were undoubtedly confounding exposures, particularly in the lead production plants, which represented one primary lead smeltery, two secondary smelteries, and three recycling plants. All the participants worked in lead industries, and there is ample evidence from biological monitoring data for the period 1947 through 1972 that there had been heavy exposure to lead. However, such data are available for less than one-third of the population and not during periods when exposures were probably the heaviest. It can also be assumed that biological monitoring concentrated on areas where high lead exposures were likely. The data base is not at present organized in a manner that permits subdividing the populations on the basis of probable lead exposure levels during various historical time periods. For this reason, one would not be justified in extrapolating from the observed patterns of mortality to risk estimates that are relevant to lead exposure levels currently used or recommended as standards.

\section{Acknowledgments}

This study was supported by the International Lead Zinc Research Organization, Inc. We wish to thank its successive presidents, Drs SF Radtke and JF Cole, as well as its managers of environmental health, DR Lynam, PhD, and RP Putnam, PhD. Members of the Organization's advisory committee who gave invaluable advice and assistance during early stages of the study were Mr KW Nelson, Mr WM Pallies, and Dr G Roush, Jr.

The original collection of the data and its organization and statistical analysis were done by WR Gaffey, $\mathrm{PhD}$. For the current update, special thanks are due Ms S Larson and Mr M Daley of Environmental Health Associates, Inc, and Ms B Walker and Ms B Speed in Dr Cooper's office.

\section{References}

1. American Cancer Society. Cancer statistics 1984. Ca-A Cancer J Clin 34 (1984) 7-23.

2. Ames BN. Dietary carcinogens and anticarcinogens. Science 221 (1983) 1256-1264.
3. Axelson O. Aspects of confounding and effect modification in the assessment of occupational cancer risk. $\mathbf{J}$ Toxicol Environ Health 6 (1980) 1127-1131.

4. Bailar JC, Ederer F. Significant factors for the ratio of a Poisson variable to its expectation. Biometrics 20 (1964) 639-643.

5. Baker EL Jr, Goyer RA, Fowler BA, Khettry U, Bernard DB, Adler S, White RD, Babyan R, Feldman RG. Occupational lead exposure, nephropathy and renal cancer. Am J Ind Med 1 (1980) 139-148.

6. Balo EJ. Experimental adenomas of the kidney produced by chronic administration of lead phosphate. Vopr Onkol 9 (1965) 144-151.

7. Boyland E, Dukes CE, Grover PL, Mitchley BCV. The induction of renal tumours by feeding lead acetate to rats. Br J Cancer 16 (1962) 283-288.

8. Coogan P, Stein L, Hsu G, Hass G. The tumorigenic action of lead in rats. Lab Invest 26 (1972) 473. (Abstract).

9. Cooper WC. Cancer mortality patterns in the lead industry. Ann NY Acad Sci 271 (1976) 250-259.

10. Cooper WC. Mortality in workers in lead production facilities and lead battery plants during the period 1971-1975. Report submitted to the International Lead Zinc Research Organization 31 January 1978.

11. Cooper WC. Mortality in employees of lead production facilities and lead battery plants, 1971-1975. In: Lynam DR, Piantanida LG, Cole JF, ed. Environmental lead. Academic Press, New York, NY 1981, pp 111143.

12. Cooper WC, Gaffey WR. Mortality of lead workers. J Occup Med 17 (1975) 100-107.

13. Cooper WC, Gaffey WR. Mortality study of lead workers. Arh Hig Rada Toksikol (Zagreb) 26 (1976) 209-229.

14. Cramer K, Goyer RA, Jagenburg R, Wilson MH. Renal ultrastructure, renal function, and parameters of lead toxidity in workers with different periods of lead exposure. Br J Ind Med 31 (1974) 113-127.

15. Dingwall-Fordyce I, Lane RE. A follow-up study of lead workers. Br J Ind Med 20 (1963) 313-315.

16. Goyer RA, Rhyne BC. Pathological effects of lead. Int Rev Exp Pathol 12 (1973) 1-77.

17. Gularek M. The influence of lead on immunity protection against tumor cells: "In vitro investigation with the LMC test." University of Dusseldorf, Dusseldorf 1981. (Doctoral thesis).

18. Kobayashi N, Okamoto T. Effects of lead oxide on the induction of lung tumors in Syrian hamsters. J Natl Cancer Inst 52 (1974) 1605-1607.

19. Lane RE. The care of the lead worker. Br J Ind Med 6 (i949) 125-143.

20. Lane RE. Health control in inorganic lead industries; a follow-up of exposed workers. Arch Environ Health 8 (1964) $243-250$.

21. Legge TM, Goadby KW. Lead poisoning and lead absorption. Edward Arnold, London 1912.

22. Lilis R. Long-term occupational lead exposure, chronic nephropathy, and renal cancer: A case report. Am J Ind Med 2 (1981) 293-297.

23. Lilis R, Gavrilescu N, Nestorescu B, Dumitriu C, Roventa $\mathrm{A}$. Nephropathy in chronic lead poisoning. $\mathrm{Br} \mathrm{J}$ Ind Med 25 (1968) 196-202.

24. Malcolm D. The effects of lead on the kidney. Trans Soc Occup Med 20 (1970) 50-53.

25. Malcolm D, Barnett HAR. A mortality study of lead workers 1925-1976. Br J Ind Med 39 (1982) 404-410.

26. Mantel N. Appendix C. In: Haenszel W, Loveland DB, Sirken MG, ed. Lung cancer mortality as related to residence and smoking histories in white males. J Natl Cancer Inst 23 (1962) 947-997.

27. Mantel N, Haenszel W. Statistical aspects of the analysis of data from retrospective studies of disease. J Natl Can- 
cer Inst 32 (1959) 719-748.

28. Mao P, Molnar JJ. The fine structure and histochemistry of lead-induced renal tumors in rats. Am J Pathol 50 (1967) $571-603$.

29. Marsh GM, Preininger M. OCMAP: A user-oriented mortality analysis program. Am Stat 34 (1980) 245-246.

30. McMichael AJ. Standardized mortality ratios and the "healthy worker effect": Scratching beneath the surface. J Occup Med 18 (1976): 3, 165.

31. McMichael AJ, Johnson HM. Long-term mortality profile of heavily-exposed lead smelter workers. J Occup Med 24 (1982) 375-378.

32. Monson RR. Analysis of relative survival and proportional mortality. Comput Biomed Res 7 (1974) 325

33. Morgan JM, Hartley MW, Miller RE. Nephropathy in chronic lead poisoning. Arch Intern Med 118 (1966) $17-29$.

34. National Center for Health Statistics. Eighth Revision International Classification of Diseases Adapted for Use in the United States. US Government Printing Office, Washington, DC 1967.

35. Oliver T. Lead poisoning. HK Lewis, London 1914.

36. Oyasu R, Battifora HA, Clasen RA, McDonald JH, Hass GM. Induction of cerebral gliomas in rats with dietary lead subacetate and 2-acetylaminofluorene. Cancer Res 30 (1970) 1248-1261.

37. Portal RW. Cerebral tumour in a lead worker. Br J Ind Med 18 (1961) 153-156.

38. Radosevic Z, Saric M, Beritic T, Knezevic J. The kidney in lead poisoning. $\mathrm{Br} \mathrm{J}$ Ind Med 18 (1961) 222-230.

39. Riggan WB, Van Bruggen J, Acquavella JF, Beaubier J, Mason TJ. US Cancer mortality rates and trends, 1950-1979. US Government Printing Office, Washington, DC 1983. (EPA-600/1-83-015a).

40. Roe FJC, Boyland E, Dukes CE, Mitchley BCV. Failure of testosterone or xanthopterin to influence the induction of renal neoplasms by lead in rats. $\mathrm{Br} \mathrm{J}$ Cancer 19 (1965) 860-866.

41. Selevan SG, Landrigan PJ, Stern FB, Jones JH. Mortality of lead smelter workers (1985). Am J Epidemiol (in press).

42. Sterling TD, Weinkam JJ. Smoking patterns by occupation, industry, sex and race. Arch Environ Health 33 (1978) $313-317$.
43. Tabershaw/Cooper Associates, Inc. Health study of lead workers. Project LH-157, prepared for the Iniernational Lead Zinc Research Organization, Inc, New York, NY 17 October 1974.

44. Tonz $O$. Nierenveränderungen bei experimenteller chronischer Bleivergiftung (Ratten). $\mathrm{Z}$ gesamte exp Med 128 (1957) $361-377$.

45. Van Esch GJ, Kroes R. The induction of renal tumours by feeding basic lead acetate to mice and hamsters. $\mathrm{Br}$ J Cancer 23 (1969) 765-771.

46. Van Esch GJ, Van Genderen H, Vink HH. The induction of renal tumours by feeding of basic lead ac state to rats. $\mathrm{Br} \mathrm{J}$ Cancer 16 (1962) 289-297.

47. Wedeen RP, Maesaka JK, Weiner B, Kipat GA, Lyons MM, Vitale LF, Joselow MM. Occupational lead nephropathy. Am J Med 59 (1975) 630-641.

48. Wen CP, Tsai SP, Gibson RL. Anatomy of the healthy worker effect: A critical review. J Occup Med 25 (1983) $283-289$.

49. Wille GW. The influence of lead on the development of pulmonary metastases after intravenous injection of syngenic tumor cells in inbred mice. University of Dusseldorf, Dusseldorf 1981. (Doctoral dissertation).

50. World Health Organization. Manual of the international statistical classification of diseases, injuries, and causes of death, based on the recommendations of the seventh revision conference, 1955. Geneva 1957.

51. Zawirska B, Medras K. Tumoren und Storungen des Porphyrinstoffwechsels bei Ratten mit chronischer experimenteller Bleiintoxikation. Zentralbl Allg Pathol Pathol Anat 111 (1968) 1-12.

52. Zawirska B, Medras $\mathbf{K}$. The role of the kidneys in disorders of porphyrin metabolism during carcinogenesis induced with lead acetate. Arch Immunol Ther Exp 20 (1972) 257-272.

53. Zollinger HU. Durch chronische Bleivergiftung erzeugte Nierenadenome und-carcinome bei Ratten und ihre Beziehungen zu den entsprechenden Neubildungen des Menschen. Virchows Arch 323 (1953) 694-710.

Received for publication: 10 December 1984 